\title{
Marksist Sanat Anlayışı
}

\author{
The Understanding of Marxist Art
}

\section{Gül Eren}

Dr. Öğr. Ü., Atatürk Üniversitesi Edebiyat Fakültesi Felsefe Bölümü, felsefetarihi@hotmail.com

\section{$\ddot{\mathbf{O} z}$}

Karl Marx, ekonomik ve toplumsal ilişkilere yoğunlaşarak kapitalist toplumun nasıl işlediğini, feodalizmin içinden nasıl doğduğunu, modern toplumdaki sınıfların üretimsel gelişimlerindeki tarihsel evrelerle nasıl bağlantılı olduğunu açıklamaya çalışır. Ekonomik ve toplumsal ilişkiler bağlamında kapitalizmin ardındaki temelde yatan sınıf mücadelelerini görünür kılarak üretici kaynakların sahibi olan burjuva sınıfının ve çalışmak zorunda olan proleterya sınıfının mücadelesini tarihsel materyalist bir bakışla ele alır. Zira Marksizm'de büyük öneme sahip olan "yabancılaşma kuramı”, “emek-değer kuramı" ve "materyalist tarih anlayışı", kapitalist toplumun nasıl işlediğini göstermek ve feodal düzenden kapitalist düzene doğru insanların ekonomik temelli ilişkilerine yoğunlaşan evrimlerini açıklayan temel kavramlardır. Bu kavramlar aracılığıyla Marks, sosyal ve tarihsel bir varlık olan insana kapitalizmin dünyasıyla ilgili epistomolojik bilgi aktarımı yaparken, insanların maddi dünyaya dair kavrayışlarını güçlendirir. Düşünceler ve kavramlar insanların maddi etkinliklerine bağımlı olduğu için sanat, toplumsal değişmenin ve dönüşmenin en etkin kuvvetidir. Maddi yaşamın karşıtlıklarından dünyaya dair bir izlenim oluşturur. Bu makalede özellikle sanatın etkin olan yönü vurgulanarak, insan yaşamının sosyo-ekonomik koşullarına entelektüel bir çerçeve çizilmeye çalışılmıştır.

Ulaşılan sonuçlar bakımından, Marksist perspektiften hareketle sanatın sosyo-ekonomik koşullara, politik etkilere yönelik ilgisini karakterize eden entelektüel faaliyet sorunlaştırılmaktadır. Marksist temellerden yola çıkan yeni sanat anlayışı ile birlikte dünyayı değiştirmeye yönelik devrimci nitelikteki pratik amaç işlevselci bir sanat görüşünü onaylayacak şekilde temellendirilmektedir. Buradan hareketle Marksist açıdan ekonomik, politik, ideolojik yapılanmalarla karakterize edildiği düşünülen sanatın ne olduğu sorusunun cevabı belirlenmektedir.

Anahtar Kelimeler: Marksist Felsefe, Sanat, İdeoloji, Entellektüel Faaliyet.

\begin{abstract}
Karl Marx expresses how capitalist society functions, how it was born out of feudalism and how it is related to the historical phases during the production developments of modern society class structure by focusing on the economic and social relations. In terms of economic and social relations, Marx deals with the proletarian struggle which has to work and the bourgeoisie that has the producer resources through ahistorical and materialist perspective by making visible the class struggles behind capitalism. For 'the theory of alienation', 'labour theory of value' and 'perception of materialist history' which are very significant in Marxism are the basic concepts explaining the evolutions focusing on the economy-based relations of human beings from feudal order to the capitalist order and revealing how capitalist societfunctioned. Through these concepts, Marx strengthens people's
\end{abstract}


insights into the material world while transferring epistomological knowledge of the world of capitalism to human being, a social and historical entity. Art is the most effective force of social change and transformation because ideas and concepts depend on people's material activities. It creates an impression of the world from the contradictions of material life. In this study, we tried to draw an intellectual frame on the socio-economic conditions of human life by emphasizing the effective aspect of art.

In terms of result achieved, the intellectual activity which characterizes the interest of Art to socio-economic conditions and politic influences is problematized. Together with new art intellection which stems from Marxist essentials, the practical purpose, which is in revolutionary trait of changing the world, is being grounded so as to approve a functionalist art view. From this point of view, the answer for the question what the art is, which is thought to characterize economic, politic, ideological structuring in terms of Marxist point of view, is being determined. Marx grounds the concept of alienation upon a dialectic and materialist philosophy within the borders of socialism which has been potentially found in

Key Words: Marxist Philosopy, Art, Ideology, Intellectual Activity

\section{Giriş}

Düşünceleriyle felsefe sahnesinde önemli bir yere sahip olan Marks, yabancılaşma konusunda Hegel ve Feuerbach'tan etkilenmiş olmakla birlikte, daha sonraları onlardan ayrılmıştır. Çünkü Hegel ve Feuerbach'a göre, yabancılaşma insanların içinde yaşadıkları hayata yabancılaşması, hayatı değersiz, boş ve anlamsız olarak görürler. Nitekim bu durum insanların kendi özlerini yanlış anlamalarından ötürü kalıc1lık arz etmez. Şayet insan gerekli felsefi bilgiye sahip olursa yabancılaşma son bulur. Marks, Hegel ve Feuerbach'ın aksine, insanların modern kapitalist toplumda sistematik bir yabancılaşmaya maruz kaldıklarını ve bunun bir yanılsama olmadığını bir gerçeklik olduğunu söyler. Bizatihi insan burjuva toplumunda kendisini boş ve anlamsız hisseder. Yabancılaşma bağlamında temel problem öyleyse, yabancılaşmış bireylerin, özgürleşme yolunda, Hegel ve Feuerbach'ta olduğu şekliyle düşsel bir takım engellerle değil de zihnin dışında bulunan gerçek engellerle karşılaşırlar. Bu anlamda yabancılaşmanın yeniden tanımının yapılması gerekmektedir. Çünkü Marks'a göre fillozoflar dünyayı sürekli yorumlamışlar ancak yapılması gereken dünyayı değiştirmektir. $\mathrm{Bu}$ anlamda yabancılaşma ancak zihin dışı bir gerçeklik alanında mücadele edilerek aş1labilir.

Marks, yabancılaşma kavramını kapitalizmde potansiyel halde bulunan sosyalizmin sınırları içerisinde diyalektik ve materyalist bir felsefe üzerinde temellendirir. Marks'1 Hegel'den ayıran en önemli unsur olan diyalektik materyalizmi ile Hegel'in fikirleri üstün bir yere koyduğu diyalektiği farklı boyutta iki yaklaşımdır. Marks, yabancılaşma kavramını ekonomik bir temele dayandırarak üretim ilişkisi üzerinden analiz etmeye çalışır. Kapitalist toplum düzeninde işçi ürettiği üründen uzaklaşır ve ona yabancılaşır. İnsanın kendi ürettiği nesneye yabancılaşması bir süre sonra kendi emeğine yabancılaşması anlamına gelir. Bu suretle insan iktisadi sistemin bir getirisi olarak başka insanların ihtiyaçlarına kayıtsız kalır ve birbirlerine yabancılaşıllar. Bu çerçevede üretici insan etkinliği ve düşünceler arasındaki etkileşime bakarak toplumsal koşullar ve tutumların insanların düşüncelerinin gelişimi ve niteliği üzerindeki etkisi[nin], düşüncelerin toplumsal koşullar ve tutumlar üzerindeki etkisinden daha fazla olduğuna işaret eder. Marks'ın analizi kapitalizmin doğasını anlatmakla kalmaz; ayrıca işçilerin kendi üretici etkinliğini, başka bir deyişle "emek güçlerini" kayıtsızlıkla sömüren kapitalist işverenlerin işçiyi emeğine yabancılaştıran süreci de eleştirir. Marks 
bu eleştiriye bir arka plan oluşturacak şekilde "değer", "mübadele değeri”, “artık değer", "meta", "sermaye", "faiz", "rant" ve "ücret" gibi kavramaları da işçi-emek bölünmesinde yardımcı basamak olarak kullanır. $\mathrm{Bu}$ kavramlardan hareketle üretimi gerçekleştiren işçinin emeğine nasıl yabancılaştırıldığını, üretim araçlarından nasıl koparıldığını ve emeğini satmaya nasıl zorlandığını göstermeye çalışır. Özellikle sınıf mücadelesi denilen şeyi bu iki temel sınıfın birbirleriyle uzlaşmayan çıkarlarını birbirleri aleyhine gerçekleştirmek için yaptıkları her şeyi içerir şeklinde tanımlar. Bu anlamda sınıf mücadelesini tarihsel materyalist bir düzlemde ele alır. Tarihsel materyalist bakış açısının içerisine insan, toplum, tarih ve sanatı da dâhil eder. İnsanların eylemlerini beden ruh ikileminde bedene vurgu yaparak sanatsal bir düzlemde yaşamı değerlendirir.

\section{Yöntem}

$\mathrm{Bu}$ çalışmada Marksist düşüncelerden hareketle entelektüel bir faaliyet olarak kabul edilen sanat anlayışının, Marksist felsefedeki yeri incelenmiştir. Özellikle Marksist felsefenin sanattan beklediği devrimci yapının, pratik bir düşünce olarak dünyayı değiştirme ve anlamasının özcü yanına vurgu yapan gönderme ele alınmıştır.

Çalışmanın giriş bölümünde Marks'ın temel kavramlarıyla birlikte düşüncenin içinde çelişik olanın yeniden üretilmesi problemi diyalektik bir düzlemde sorunlaştırılmıştır. Bu eksen çerçevesinde takip eden paragraflarda Batı medeniyetinin mutlak aklını temsil eden politik iktidarının tikelliğine karşı geliştirilen söylem değerlendirilmiştir. Özellikle Batı kültür tarihine kaynaklık eden mutlak akılın hegemonik bir otoriteye tekabül eden tahakküme dayalı söylemlerinin eleştirilerine yer verilmiştir. Duyusal bireysellikleri hesaba katmayan, tahakküm eden hegemonik otoriteyle, Marksist literatürde köle diye adlandıracağımız yığınlar arasında estetik olanın yeri belirlenmeye çalışılmıştır. Sonunda, Marks açısından aklın tümellikleri ile duyuların tikellikleri arasındaki estetiki bağlam sanat, akıl, bilim, ideoloji, ekonomi-politik düzlemde ifade edilmiştir.

\section{Marksist Sanat Anlayış̧ı}

Karl Marks, ekonomik ve toplumsal ilişkilere yoğunlaşarak kapitalist toplumun nasıl işlediğini, feodalizmin içinden nasıl doğduğunu, modern toplumdaki sınıfların üretimsel gelişimlerindeki tarihsel evrelerle nasıl bağlantılı olduğunu açıklamaya çalışır. Ekonomik ve toplumsal ilişkiler bağlamında kapitalizmin ardındaki temelde yatan sınıf mücadelelerini görünür kılarak üretici kaynakların sahibi olan burjuva sınıfının ve çalışmak zorunda olan proleterya sınıfının mücadelesini tarihsel materyalist bir bakışla ele alır. Bu sayede, 19. yüzyılın topluma yönelmiş olan felsefesini devrimci ideolojik bir mantıkla farklı bir zemine taşır. Özellikle 1846-47 kışında Proudhon'un Sefaletin Felsefesi'ne karşılık olarak yazılan Felsefenin Sefaleti'nden çok daha önce Marks kendini yeni bir tür sosyalizm kuramcısı ya da filozofu olarak ütopyacılığın herhangi bir anlatımına dayanmayan hatta varoluşla uygunluk içerisinde olmayan bilince işaret ederek somut olarak var olan güçlerin gerçekliğinin kabul edilmesi gerektiğini ilan eder (Türdeş, 2004, s. 57). 19. yüzyılın toplum felsefesi geleneğinin kendine özgü doğas1 içerisinde, varoluşu aşkınlaştıran ve Batı kültür geleneğinin teorik düzlemindeki Cartesian entelektüel atmosferinden radikal bir kopuşun emaresi olarak Kant'tan sonraki felsefi uyuşmazlıkları, idealistpozitivist çerçevenin dışında tartışır. Bağlamından kopmuş aklın tümellikleri ile duyunun tikellikleri arasında pratik amaca hizmet edecek şekilde yeni bir felsefe ortaya koyar. Kant'in epistemolojik Kopernik Devrim'ini sürdürmeye çalsşan Alman idealistleri Fichte, Schelling ve Hegel'in devam ettirmeye çalıştığı aklın ayrıcalıklı konumunu eleştirerek Batı kültürünün büyük sistemli felsefelerini sorunsallaştırır (Rockmore, 2014, s. 79). Özellikle Hegel ile radikal bir karşıtlık içerisine girerek dünyayı anlama ve anlamlandırma problemini, dünyayı değiştirme problemine dönüştürür. Bunu yaparken sadece ekonomi-politik bir yaklaşım sergilemek şöyle dursun tarihsel bir bakış açısı da kullanır. Tarihsel materyalizmiyle birlikte toplumların ve kültürlerin değişimlerini bir sosyolog edasıyla 
izah eder. Önemli olan insanlık tarihinin içinde barındırdığı zorunlu olan değişimlerdir. Politik ya da tarihsel bir karabasan karşısında insanlık tarihi, kaçınılmaz olarak diyalektik bir karşıtlık içerisine girer.

Hegel'den aldığı diyalektik yöntemi materyalist bir eksende işleyen Marks, insan hayatı üzerindeki materyalist etkileri tarihsel bir perspektifte bir araya getirir. Marksist düşünür Eagleton da, Marks'ın materyalist yöntemi hakkında "araştırmaların bir yol gösterici ilkesi olarak değil de, kişiye uygun gelen bir tarih şablonu gibi kullanılırsa, o zaman karşıtına dönüşeceği” ifadesini yineler (Eagleton, 2011, s. 68). (Bkz. Marx \&Engels, 1995). Marks materyalizmini oluştururken toplumun yapısında var edilmeye çalışılan vaatleri, bir yana bırakarak idealist vaatlerin karşısında duyu deneyini onaylayan bir sistem benimser. Etki gösteren her somut yaşamsal düzen özel niteliğiyle materyalist bakış açısının içerisine girer. Ancak bu yapısal şekiller Marks'ta ekonomik-güçsel oluşumun özel şekilleri olarak algılanıp nitelenir. Öncelikli olarak insan, tarih ve toplum içinde yaşayan bir varlık olması nedeniyle, varlık ve gerçeklik arasındaki ilişki önem arz eder. Çünkü Batı kültür tarihinde varoluş, daima aşkınlaştıran düşüncelerle sarılı olmuştur. Marks için, gerek felsefi gerek ahlaki temeller üzerinde varoluşa dair aşkınlaştırıcı düşünceler, ekonomik-politik eksende ideolojiktir. Devrimci bir etkinlik olmaktan ziyade, yaratılan dünyanın maskeleridir (Mannheim, 2004, s. 219). Varoluş ve buna bağlı olarak varoluşsal aşkınlık, salt maddi bedenlerin varlığını kabul etmek yerine, akıl yoluyla temellenmiş cisimsel olmayan ruhların varlığını onar. Aşkınlaştırıcı bir mekân veyahut öteki dünya gibi metafiziksel kavramlar insanların eylemlerini içine alıp geleceğe dair vaade dayalı bir umut sistemi yaratır. Doğaüstücü bu düşünceler beden ile ruh arasına bir ayrılık sokarak düalite problemine sebebiyet verir. Varoluşsal aşkınlık kavramında temellenen büyük felsefi sistemler beden ve ruh üzerinden bedenin içgüdülerini, arzularını ve isteklerini küçümseyerek ilerler. Sosyal düzen tarafından davranışlarına ket vurulan insan modern kavramlarla birlikte zincire vurulur. Marks'ın materyalizmine göre düşünce eylemden ayrılamaz yani teorinin pratikten ayrı düşünülmesi söz konusu değildir. Böylesi bir ayırımı Felsefenin Sefaleti'nde Marks, Proudhon'un ruhu evrensel bilincin bir parçası saymasından ötürü reddeder (Marks, 1966, s.146). Bu reddediş bilimsel ilerleme ve pratik gelişmelerle bağlayıcılık içerisinde genel bağdaşımları aşarak, gerçekte var olan tüm yaşamsal düzenlerin tefekkürüne yönelir. Bu noktada Marks, yaşamsal düzenler üzerine kültür eleştirisini diyalektiğin en son aşamasında gündeme getirerek felsefeyi, sanatı, dini, ahlakı ekonomi politik bir düzlemde ele alır.

İnsan, doğa durumundan sosyal düzenlemeler ve toplum sözleşmeleriyle birlikte hegemonik bir yönetenin varlığında rolleri belirlenmiş bir yapının içindedir. Bu yapıda bireyler, ekonomik koşulların koşullanmış öğeleri olarak yerini alır. Ekonomik bir sınıfın bireyleri olmaları nedeniyle üst yapı-alt yapı ilişkileri içerisinde çatışan bir dünyada yaşamlarını idame ettirirler. Marks, bu çatışmayı Komünist Manifesto'nun daha ilk başında sınıf mücadelesi olarak betimler (Marks \& Engels, 2018, s.52). Bu atmosfer içerisindeki tartışmalarda sanat, politik iktidarın eşgüdümünde sınıfsal çatışkının içerisindedir. Marksist düşüncenin pratik ve dönüşüme dayalı etkinliği dikkate alındığında sanatta tıpkı felsefe ya da bilim gibi dünyayı devrimsel nitelikte değiştirmelidir. Her şeyden önce sanatın, estetik bir bilinç olarak aklın tümelliklerinde sadece dünyayı anlamaya yönelik bir gayesi yoktur. Şayet böyle bir gayesi varsa, bireyin toplum içindeki rolünü göz ardı eder. Hegelvari bir biçimde idealist bir yaklaşımla toplumsal gelişmede bireyin arzularını ve isteklerini bir kenara bırakarak nesnel ve mutlak bir tinin haklılaştırılması peşinden gider. Tez, antitez ve sentezden oluşan diyalektik bir yöntemle mutlaklık iddiaları içinde nesnel bir hakikat arama isteğiyle duyunun tikelliklerindeki eserlere yabancılaşır.

Yabancılaşma kavramı Marks'ın felsefesinde önemli dönüm noktalarından birisidir. Marks, yabancılaşma konusunda Hegel ve Feuerbach'tan etkilenmiş olmakla birlikte, daha sonraları onlardan ayrılmıştır. Çünkü Hegel ve Feuerbach'a göre, yabancılaşma insanların içinde yaşadıkları hayata yabancılaşması, hayatı değersiz, boş ve anlamsız olarak görmeleri anlamına gelir. Nitekim bu durum insanların kendi özlerini yanlış anlamalarından ötürü kalıcılık arz etmez. Şayet insan gerekli felsefi 
bilgiye sahip olursa yabancılaşma son bulur. Marks, Hegel ve Feuerbach'ın aksine, insanların modern kapitalist toplumda sistematik bir yabancılaşmaya maruz kaldıklarını ve bunun bir yanılsama olmadığını aksine bir gerçeklik olduğunu söyler. Bizatihi insan burjuva toplumunda kendisini boş ve anlamsız hisseder. Yabancılaşma bağlamında temel problem öyleyse, yabancılaşmış bireylerin, özgürleşme yolunda, Hegel ve Feuerbach'ta olduğu şekliyle düşsel bir takım engellerle değil de zihnin dışında bulunan gerçek engellerle karşılaşırlar. Bu anlamda yabancılaşmanın yeniden tanımının yapılması gerekmektedir. Çünkü Marks'a göre filozoflar dünyayı sürekli yorumlamışlar ancak yapılması gereken dünyayı değiştirmektir. Bu anlamda yabancılaşma ancak zihin dışı bir gerçeklik alanında mücadele edilerek aşılabilir. Şu halde, Marksist sanat anlayışı insanın iç dünyasına yabancılaşmadan gerçeklikle iç içe geçmiş bir helezon gibidir. Aristoteles’ten beri düzene sokulmaya çalışılan doğa, idealize edilmiş bir doğadır. Varoluşla uygunluk içinde olmaktan ziyade olması gerekeni belki de ütopik bir bilinçle ortaya koyar. $\mathrm{Bu}$ anlamda gerçeklikten uzak, ideal olan bir dünyayı yansıtan sanat anlayışı zuhur eder. Gerçeklikten uzak, varoluşu aşkınlaştırıcı etmenler doğrultusunda yaşamın düzeni kurulur. Ki bu tartışma sanat felsefesinde görünüş-gerçeklik ikilemini gündeme getirir. Sanatçı görünüşün ötesindeki gerçekliği görebilmelidir. Her ne kadar Platon Devlet'inde sanatçıları, mimesis öğretisiyle taklitçi olarak nitelendirse de Batı dünyasının Neo-Platoncu yansımaları gerçek dünyayı yansıtmayan, ideal dünyanın üzerine kurulur. Varoluşun bu türden aşkınlaştırılmasındaki amaç, "yani belli bir yaşamsal düzende gerçekleştirilmesi mümkün olmayan içeriksel değerlere ve istemlere sürekli baskın gelmek, bu türden içeriksel değerleri toplumun ve tarihin ötesinde olan bir mekâna sürgün ederek," toplumsal açıdan etkisiz hale getirmekti (Mannheim, 2004, s. 218). O halde sanat eseri, nesneleri olduğu gibi değil de, nasıl olması gerekiyorsa o şekilde tasvir eder. Dünyada çirkin, hoşa gitmeyen şeyler olduğu halde, sanat eseri yalnızca güzel ve hoş olanı seçer (Moran, 2008, s. 34). Nitekim dünyada yalnızca güzel, hoş olan şeyler yoktur. Acı, keder, 1stırap, üzüntü yaşamın bir diğer yüzüdür. Nietzsche'nin de belirttiği üzere yaşam hem üzüntünün hem de mutluluğun yer aldığı bir tragedya sahnesidir (Bkz. Nietzsche, 2002). İdealleştirilmeye çalışılan bu dünya yalnızca idealar dünyasının bir yansıması olarak pür mutluluğun, güzelliğin ya da barışın hüküm sürdüğü bir düzen değildir. Aksine Marks'a göre bu dünya ezenlerle ezilenler arasında kesintisiz bir mücadelenin olduğu, ekonomik temelli bir üretim ilişkileri ağıdır. Buradan hareketle, Marksist sanat anlayışının öncelikli olarak sanatın içinde yeşerdiği ekonomik, politik ve toplumsal koşullarla karakterize olduğu söylenebilir. Marks sanat ve yazını, "yalnızca kendi iç gelişme yasalarından hareket edilerek kavramanın kesinlikle olanaksız olduğunu" düşünüyordu. Sanatın özü, kökeni, gelişimi ve toplumsal işlevi (rolü), yalnızca ekonomik etkenin -üretici güçlerin gelişiminin üretim ilişkileriyle olan karmaşık etkileşiminin- belirleyici rol oynadığı, tüm olarak toplumsal sistemin tahliliyle anlaşılabilir" (Marx \& Engels, 2009, s. 13). Hatta üretici insan etkinliği olarak sanat, toplumsal koşullar ve tutumların insanların düşüncelerinin gelişimi ve niteliği üzerindeki etkisi[nin], düşüncelerin toplumsal koşullar ve tutumlar üzerindeki etkisinden daha fazla olduğuna işaret eder. O halde sanat, Marks için insanın toplumsal varlığının bir parçasıdır.

Toplumsal varlık olarak insan, rekabet eden, çekişen, çatışan yönleriyle tarih sahnesinde kendi varoluşunu ortaya koyar. Sanatın toplumsal niteliği de bu çekişmeler ve çatışkılardan etkilenir. "Şimdiye kadarki bütün toplumların tarihi, sınıf mücadelelerinin tarihidir. Özgür insanlarla köleler, patrisyenlerle plebler, baronlar ve serfler, lonca mensubu yurttaşlarla kalfalar, kısacası ezenlerle ezilenler arasında her zaman çelişki vardı, bunlar birbirlerine karşı kâh gizli kâh açık kesintisiz bir mücadele yürüttüler, her defasında tüm toplumun devrimci bir dönüşümüyle veya mücadele eden sınıfların beraberce çöküşüyle sonuçlanan bir mücadeleydi bu" (Marx \& Engels, 2018, s. 52). Başka bir deyişle işçilerin kendi üretici etkinliğini, emek güçlerini kayıtsızlıkla sömüren kapitalist işverenlerin işçiyi emeğine yabancılaştıran süreçleri, "değer", "mübadele değeri”, “artık değer", "meta”, "sermaye”, “faiz”, "rant” ve "ücret” gibi kavramaları da kapsayacak biçimde üretimi gerçekleştiren işçinin emek mücadelesi. Marksist perspektifte sanat, sınıf mücadelelerinin, sınıf politikalarının ve ideolojilerinin etkisi altındadır. Üst yapı 
ve alt yapı bağlamında sanat eserleri, oluşturuldukları tarihin, dönemin politik ve ideolojik ilişkilerinin birer ürünüdür. Her tarihsel dönem kendi estetik değerlerini yaratmıştır. Horkheimer'ın söylemiyle, Mutlak'ın kendisi bile her ne kadar nesnel ve genel olursa olsun en nihayetinde öznel amaçlara hizmet eden bir şemaya dönüşmüştür (Horkheimer, 2008, s. 97).

Estetik bilinç Marksist sanat anlayışı ekseninde, tarihsel materyalistik bir düzlemde, açıklanarak duyu deneyimine dayalı dış dünyayla bağlantılı bir hale getirilir. Estetik olanın algısı idealize edilmiş alandan soyutlanarak dış dünyadaki insanın emeğine içkinleştirilir. Düşünceden ayrılmayan maddi bedenler, doğaüstücü bir anlayıştan ayrılarak kendilerini emeğin etkisine bırakır. Kültürün temeli emektir. Bilimsel yöntemden, deneyden beslenen bu düşünce, Antik Yunan'dan itibaren birçok filozof tarafindan benimsenen estetiki duygunun doğuştan olduğu fikrini reddeder. Çünkü estetiki duygu, toplumların genel oluşum şartları içerisinde gelişen bir aşamadır. Bir anlamda her şeyin yolu ekonomiye çıktığı için sanatta doğuştan değil de, maddi koşullarla birlikte şekil kazanır. Marks Alman İdeolojisi'nde, "ilk tarihsel eylemin maddi ihtiyaçlarımız karşılanması için üretim yapmak olduğunu" yazar. Ancak bundan sonra sanat yapabiliriz. Kültürün temeli emek olduğuna göre, maddi üretim olmaksızın uygarlıkta var olamaz. Maddi üretim ve uygarlığın var olmadığı yerde sanattan bahsetmek söz konusu değildir. Marks bu durumu bir adım daha öteye taşıyarak maddi üretimin nihai uygarlığın niteliğini de belirlediğini söyler. Eagleton'ın da belirttiği üzere, maddi üretimin uygarlığın niteliğini belirlediği yönündeki genel bağlam, sanat eserlerinin biçim ve içeriğini, bu eserlerin içinde oluştuğu ekonomik, politik, sosyokültürel, ideolojik ilişkilerle açıklamak olasıdır (Eagleton, 2011, s. 126). Marks'ın hareket noktasını oluşturan öncüller, keyfi temeller ya da dogmalar değildir; bunlar gerçek bireylerdir, bu bireylerin eylemleri ve maddi yaşam koşullarıdır. Marks'a göre bu koşullar ancak ve ancak ampirik olarak oluşturulabilir. O halde "tüm insan tarihinin ilk öncülü canlı bireylerin varlı̆̆gdır. Şu halde saptanması gereken ilk olgu, bu bireylerin fiziksel örgütlenişleri, ve bu örgütlenmenin sonucu olarak ortaya çıkan, doğanın geri kalan bölümüyle olan ilişkileridir" (Marks \& Engels, 2004, s. 19). Fikirlerin, tasavvurların ve bilincin üretimi, başlangıçta, insanların maddi faaliyetiyle ve aralarındaki maddi temaslarla, yani gerçek hayatın diliyle doğrudan bağlantılıdır. Söz konusu sanatsal yaratım kapitalist toplumun planlama sürecine nasıl uyum sağlayacak?

İnsanların maddi davranışlarının bir ürünü olarak sanat, düşünme, tasavvur etme türünden zihinsel etkinliklerde bulunurken, sanatçı ve sanat ürünü üzerinden yola çıkar. Bireyin toplum içindeki yeri, rolü ve tercihleri nasıl maddi bir üretimin bir yansımasıysa, sanatçı ve sanat ürününün biçim ve içeriği de yine maddi üretimin yani toplumun ekonomik, politik ve ideolojik koşullarının bir yansımasıdır. Bundan ötürü Marksist sanat anlayışında dünyanın bir yansımasını görürüz. Ancak bu yansıma çift yönlüdür. Bir yandan nesnel ve maddi süreçlere dayandığ 1 için bilimsel, diğer yandan toplumun ekonomik, politik şartlarını yansıttığı için ideolojiktir. Bu durum sanatçıyı ve sanatçının ürettiklerini tabi olduğu tarihin şartlarıyla sınırlandırır. Michael Albert'in Kapitalizm Ötesinde Yaşam'da Sanat başlıklı kısmında sanatçının komiteler ve katılımcı ekonomiyle bireylerin yaratıcılığının nasıl sınırlandırıldığına dair yönelttiği soru bu çerçevede dikkat çekicidir (Albert, 2007, s. 182). Her ne kadar tasavvurları, fikirleri vb. üretenler insanların kendileri olsa da; sanatsal yaratım, maddi dünyanın ve toplumun üretici güçlerinin belirli bir gelişim düzeyini incelemez. Aksine sanatsal yaratım, maddi ilişkiler tarafından kaçınılmaz olarak koşullanan dünya ve toplumların gelişmesi doğrultusunda üretir ve değişir. Söz konusu durum sadece sanat için değil aynı zamanda ahlak, din, felsefe için de geçerlidir. Bilinç, asla bilinçli varlıktan başka bir şey olamaz; insanların varlığı da onların gerçek yaşam süreçleridir. Sanat, insanların tarihsel yaşam süreçlerinden ileri gelir. İşte bu yüzden, sanat dünyayı olduğu gibi göstermek yerine, yaşanılan tarihsel dönemin estetik değerlerine göre dünyayı olduğunu sandığı şekliyle yansıtır. Dolayısıyla bir yorumlar çokluğu söz konusudur. Şayet böyle olmasaydı, kaçınılmaz bir bütünselleştirici ufuk içinde sanat, genel kurallara, hukuki-ahlaki tasarımlara ya da ölçülere indirgenme tehlikesine düşer 
(Derrida, 2007, s. 55). tıpkı Marks'ın Alman İdeolojisi'nde Genç Hegelcilerin eleştirini yaparken, gökyüzünden yeryüzüne inen Alman felsefesinin Hegel'in sistemli felsefesi zamanında yeryüzünden gökyüzüne çıkmasında söylediği gibi. Hâlbuki insan, düşündüklerini, hayal ettiklerini, kavradıklarını tasarımlanmış bir dünyadan yola çıkarak değil aksine, bu yaşam sürecinin ideolojik yankı ve yansımaları içindeki gerçeklikten çıkarır. Etkin ve aktif olan birey, düşüncelerindeki hayalleri, ampirik olarak kanıtlanabilir olan alana izafe eder. Bu suretle sanat, maddi temellere dayanan kendi maddi yaşam süreçlerinin yüceltilmiş bir yansıması halini alır. Antikçağdan bu yana aşkınlaştırılmış bir alana izafe edilen sanat, üstün bilincin alt katmanı olmaklıktan çıkar. Evrensel bir yapının pasifize edilmiş etkinliği olmak yerine insanların maddi üretimlerinin ve maddi ilişkilerinin gelişmesiyle paralel giderek, kendini geliştirir ve değiştirir. O halde Hegel'in söylediği gibi insan yaşamını tamamen belirleyen "kendisine tekillik biçimini”" veren kararlaştırıcı bilinç değildir (Marks, 2016, s. 33). Tersine, bilinci belirleyen yaşamdır.

Toplumun gelişme düzeyinin ve toplumsal yapısının sanat yapıtların biçim ve içeriğini belirlediği olgusu, Neo-klasik çağdan sonra gelen romantizm akımına karşı bir tepkidir. Çünkü Marks, idealleştirilmiş yaşamın gerçeklikten uzak konularının aksine, gerçek yaşamı, gerçek toplumu konu edinen gerçek sanatçıdan taraf olur. Belirli koşullar altındaki insanlar, gerçeğe ampirik olarak ulaşır. Her ne kadar sanatın, hayal gücünün eseri olan bir yapısı söz konusuysa da; bu sanatın düşsel nesnelerin bir faaliyeti olması anlamına gelmez. Başka bir deyişle, Marks'ın Kapital'de kullandığı, (Bkz. Marks, 2003) sistemsel ve yaşanan olmak üzere çift yönlü kriz kavramları arasında kurduğu bağıntı ile insanların pratik gelişim ve değişim süreçleri ile değişime direnen süreç arasındaki bağıntı sanatın, bilim ve ideolojinin neresinde olduğunu açıklı̆ga kavuşturur ${ }^{1}$ (Benhabib, 2005, s. 143). Marksist felsefi düşüncede sanat, bilimin dünyanın olduğu gibi yani gerçekte ne ise o şekilde algılanması gerektiği yönündeki düşünüşüyle, sistemlerin değişime olanak tanımayan ve kasıtlı olarak gerçekliği çarpitan ideolojik düşünüşünün arasındadır. Tarihi toplumsal bir varlık olan insan, sistemin genel bağlamı içerisinde karakterize olur. Çıkarlar uğruna gerçekliklerin çarpıtıldığı ortamda insan, dünyayı sistemin düşündürdüğü şekliyle algılar. Bu yüzdendir ki sanatın bir yanı tarihsel olarak sınırlandırılmış algılardan ötürü ideolojiktir. Ancak insanların tarihsel gelişiminin gözleminden elde edilen sınırlı algıların, gerçekliğinden koparılması sanatın hayal gücüne dayalı olan yönünü dışarıda bırakır. Başlı başına ideolojik olan sanatın hiçbir değeri yoktur. Ancak yaşanan bir dünya vardır ve bu dünyada gerçekliğe dayalı olan düşünceler, düşüncelerden ayrı tutulamayacak eylemler söz konusudur. Bu yönüyle sanat, bilime yaklaşır. Sanatın bilime yaklaşması demek, maddi olanın tasnif edilip yeniden düzenlenmesi demek değildir. "İnsanlar kendi tarihlerini kendileri yaparlar, ama istedikleri gibi değil, kendilerinin seçtiği koşullarda değil doğrudan karşılaşılan, verili ve geçmişten gelen koşullarda yaparlar. Bütün ölmüş kuşakların geleneği, yaşayan kuşakların beynine bir karabasan gibi çöker" (Marks \& Engels, 2009, s. 74). Sanat, maddi dünyayı ve toplumu tarihiyle birlikte incelerken geçmişten gelen koşullar üzerinden yükselir. Nitekim her sanat yaratımı kendi tarihsel evresinin koşulları altında gelişir ve değişir. Farklı dönemlerdeki sanat eserleri kendilerini yinelemez. Örneğin Antikçağdaki Homer'in şiirlerini yaşadığımız çağda yeniden oluşturmak mümkün değildir. Çünkü sanat eserleri sadece yaşanılan çağın izlerini taşır. Bu anlamda sanatın doğayı ve toplumsal ilişkileri görüş tarzı son derece önemlidir. Bireyin içinde yaşadığı duyusal dünyanın, değişmeyen, hep aynı kalan bir yanı yoktur. Sanayinin ve kapitalist düzenin, toplumun ihtiyaçlarına göre şekillenen tarihsel bir geçmişe bağımlılığı sebebiyle kendinden önceki toplumun tarihselliği üzerinden yükselen bir yapısı vardır. Bu yapı toplumun ve değişen zamanın ihtiyaçlarına göre kendini geliştirir ve değiştirir. Bu yüzdendir ki Marksist

\footnotetext{
${ }^{1}$ Marks'ın Kapital adlı kitabında kullandığı sistemsel ve yaşanan olmak üzere çifte kriz kavramı arasında nasıl bir bağıntı olduğu ve bu iki perspektifin eleştirel bir toplum teorisinde birbirini dışlamadığının tartışması Seyla Benhabib'in Eleştiri, Norm ve Ütopya adlı kitabından incelenebilir.
} 
düşüncede sanat, toplumu değiştirmeye yönelik devrimci bir harekettir. Estetiğin Baumgarten'le başlayan duyusallık ülkesini sömürgeleştirme girişimi, Marksist estetik anlayışın devrimci ve ilerlemeci karakteriyle varoluşun duyusallık dünyasını kurtarır (Hünler, 2011, s. 93). Sanat gibi her toplumsal biçimleniş, duyusal biçimleniş ile karşılıklı olarak bir etkileşim içine girer. Sanat; etkindir, devrimseldir, aktiftir ve ilerlemecidir. Fakat bu ilerlemenin, etkin ve aktif olma durumunun idealizm ile materyalizm arasındaki karşıtlıkla bir ilgisi yoktur. Estetiki yaratım, tamamiyle üst ve alt tabakadaki insanların toplumsal yaşamının ve ideolojisinin mekanik ya da bilinçli tümelliklerin bir yansıması değildir. "Estetiğin söylemi, duyuyla tin, arzuyla akıl arasında korkunç bir yabancılaşma görür; ve Marks'a göre bu yabancılaşmanın kökeni tam da sınıflı toplumun doğasındadır" (Eagleton, 2010, s. 257). Kapitalist toplumun diktatörlüğündeki sınıfsal hiyerarşiye dayalı olan çarkta sınıf mücadelesi mevcuttur. Komünizme geçiş aralığında duran eski düzende insan bedeni ortadan kalkmıştır. Kapitalist sömürü güçleri kurdukları dünyada insanları bedensizleştirir. Marks'ın bu geçiş dönemi için eksik ve sınırlı olan ifadeleri, politik alanda geçerli olduğu gibi işçilerin durumu göz önüne alındığında ekonomik alan için de geçerlidir. Marks bu evrede işçilerin durumunu, çalışma koşullarının ıslahı ve üretim süreci insanının katlanılır olanaklara sahip olması anlamında ele alır ve bu anlam herkesin çalışıı̆̆ çalışanlar arasındaki eşitsizliğin ortadan kalktığı ve herkesin kendi tasarrufuna kalan boş bir zamana işaret eder. Ancak Marks için bu boş zaman, emeğin bir kaybı değil aksine herkesin çalışmak zorunda olduğu bir toplumda çok yoğun bir şekilde gerçekleştirilmiş olan emeğin, üretici insana bıraktığı boş zamandır. Asıl önemli olanın planlama olduğu ve bu planlamanın amacının da ihtiyaçların karşılanmasına yönelik olmasıdır. Ancak kapitalizmin elindeki maddi koşullar boş zamanların yaratılması bir yana insan bedenini kendisine yabancılaştırır. Böylece bedeni kaybolmuş ruhsal bir durum yaratılır. Tam tersi yönde de, sermaye kapitaliste zenginliği sağlayacak şekilde güce bürünmüş bir bedensel varlık sağlanır. Bedensel varlığın garantisi ise, metaların bu dünyadaki maddi kullanım değerleriyle sabitlenir. Tarihsel ve toplumsal bir varlık olan insan, bu mücadele dünyasında var olabilmek adına bütünün bir parçası olmaya çalışır. Ne yazık ki bu uğraşı sadece bedenin duyusal yönünü tüketir. Burjuvazi toplumundaki ilişkilerin sınırl, yüzeysel, zorla ve bilinçsiz oluşu karşısında insan, ortaya koyduğu emeği için acımasızca bir savaşım içerisine girer. Mevcut güçlerin üretimin bir parçası olarak kendisini tahakküm altına alma, bir şeyleri yapmaya zorlama ve sıradanlaştırma sürecini ortadan kaldırmak ister. Zira bu durum Marks'ın 1srarla üstünde durduğu ve bütün dünyayla hem düşünsel hem de maddi anlamda fiili bir ilişkiye girmek için dünya çapında ele aldığı bir sorundur. Eğer dünya çapında bir ilerleme kaydedilecekse bireylerin bilinçlerine işleyen devrimsel nitelikte bir basamak oluşturulmalıdır.

Nitekim kapitalizmin doğayı ve insanı giderek kendi çıkarları uğrunda araçsallaştırması, bedensel hazdan uzaklaşmış homojen kalıplar yaratır. Duyu ve tin arasındaki uçurum giderek daha da derinleşir. Estetik olarak biçim ve içeriğin uyumu sağlanamaz. "Bu nedenle bu ikilem varlığını insan bedeninde sürdürür: Bedenin üretken güçleri akılsallaştırılıp metalaştırılırken, simgesel, libidinal dürtüleri soyutlanarak kaba zevklere dönüştürülür ya da gereksiz bulunarak dışlanır. Bu güçler emek sürecinden çıkarılarak ikincil önemdeki üç bölgeye kanalize edilirler: Sanat, din ve cinsellik...Kapitalist toplum, aynı anda hem böyle anarşik bir arzunun orjisi, hem de bedensiz aklın krallı̆̆ıdır” (Eagleton, 2010, s. 258). Kimi zaman kapitalist üretim sanatın insancıl hedeflerini ve umutlarını yok eder. Bu tutum karşısında sanat bir diğer ifadeyle özgür olmak isteyen bilinç, kapitalist gerçeklik ile hayalleri arasında çelişki içine girer. Marks'a göre, dünyadaki insanın bu trajik çatışması esasen sanatın diyalektik özelliğinden kaynaklanır. Kendini gerçekleştirme yolunda özüne yabancılaşan insan, diyalektik yöntemle kapitalist toplumun dayatmalarını sanatsal bir eleştiriye tabi tutar. Bedensiz aklın krallığında sanat, egemen sınıfın çıkarlarına hizmet edecek biçimde eserlerini oluşturur. Egemen sınıfın konumuna göre değerlendirmeye tabi tutulurlar. 
Marks, edebiyat ve sanatı incelerken, dikkatini tarihsel çağın özelliğini açıklamasına yöneltir. Dünyanın gerçekçi görünümlerinin ötesine geçerek, o toplumu ve kültürü oluşturan esas yapının ışığında sanatı irdeler. Romantik akıma karşı realistik bir tavır takınır. Marks, Minna Kautsky'nin Eskiler ve Yeniler adlı romanını incelerken yazarın kendisine, tuz madeni işçilerinin yaşamını, Stefan'daki köylülerin portresini ya da Viyana sosyetesinin yaşamını gerçekçi bir tavırla ortaya koymasından ötürü teşekkür eder. Ona göre, Viyana sosyetesinin yaşamının gerçekçi izlenimini veren kentin kendine özgü uluslararası karakterinin Avrupalılarla iç içe geçmiş olan yapısıdır. İdeolojik içerik ile gerçeklik iç içe geçmiş durumdadır. Marks özellikle diyalektik ve materyalist bilgi teorilerini sanat ve edebiyatın tahliline uygular (Marks \& Engels, 2009, s. 81).

Maddi yaşamsal ekonomik kategoriler estetiktir. Üretken emek, kapitalist üretim açısından sermayeyle doğrudan ilişkili olan emektir. Emeğin üretim koşullarını belirleyen para ya da meta olsun genel olarak değeri, öncelikli olarak sermayeye dönüştüren değişimle tanımlanır. $\mathrm{Bu}$ tanımlar, emeğin maddi özelliklerinden değil, ama belli bir toplumsal biçimden, emeğin içinde gerçekleştirildiği toplumsal üretim ilişkilerinden çıkar. "Örneğin bir aktör, hatta bir palyaço, ücret olarak aldığından daha fazla emeği geri döndürdüğü bir kapitalistin (girişimcinin) hizmetinde çalışıyorsa, bu tanıma göre, üretken bir emekçidir; ama buna karş1lık kapitalistin evine giden ve pantolonunu onaran gündelikçi bir terzinin emeği, kapitalist için yalnızca basit bir kullanım-değeri ürettiği için üretken-olmayan bir emektir" (Marks, 2009, s. 132). Üretken olan ve olmayan emek, emekçi açısından değil, kapitalist açısından işlenir. Marks'a göre meta, duyu ile tin, biçim ile içerik ya da tümel ile tikel arasındaki ilişkilerin farklı bir boyutudur. Bazı toplumsal koşullarda tinseldir, bazılarında ise duyusaldır. Marks, değeri olgunun içine sokarak duyu-tin arasındaki belirsizliğe sürüklenen çatışkıyı bir değişim değerine dönüştürür. Maddi olmayan üretim, salt değişim için gerçekleştirildiği, yani meta ürettiği zaman bile, iki türlü olabilir:

1. Üreticilerden ve tüketicilerden bağımsız ve ayrı bir biçime sahip olabilen metalarda, kullanımdeğerlerinde ortaya çıkabilir; bu metalar, üretim ile tüketim arasındaki süre boyunca varolur ve bu süre içinde, kitaplar resimler gibi satımlık metalar olarak, tek sözcükle, sanatçının sanatsal performansından ayrılabilen tüm sanat ürünleri olarak dolaşımda kalabilir. Burada kapitalist üretim çok sınırlı bir çerçevede sözkonusudur: örneğin ortak bir yapıtın -diyelim bir ansiklopedinin- yazarı, başka kişileri kiralık yazarlar olarak kullandığı zaman. Bu alanda, çoğu kez, kapitalist üretime bir geçiş biçimi geçerli olur; o biçim çerçevesinde çeşitli bilimsel ya da sanatsal üreticiler, zanaatçılar ya da uzmanlar, kitap ticaretinin ortak ticari sermayesi için çalışırlar -bu ilişkinin asıl kapitalist üretim tarzı ile bir ilişkisi yoktur ve hatta biçimsel olarak bile henüz kapitalist üretimin egemenliği altına alınmış değildir. Bu arageçiş biçimlerinde merak sömürüsünün en üst noktasında oluşu gerçeği bu durumu hiçbir biçimde değiştirmez.

2. Ürün, üretim eyleminden ayrılamaz - tüm gösteri sanatçıları, konferansçılar, aktörler, öğretmenler, doktorlar, rahipler vb. için durum budur. Burada da kapitalist üretim tarzıyla ancak sınırlı bir dereceye kadar karşılaşılır ve bu etkinliğin doğası gereği, pek az alanda uygulanabilir. Örneğin eğitim kurumlarındaki öğretmenler, kurumun girişimcisi için yalnızca birer ücretli-emekçi olabilirler, İngiltere'de bu tür birçok eğitsel fabrika vardır. Gerçi öğrenciler söz konusu olunca, bu öğretmenler üretken emekçi değildirler; ancak kendi işverenleri söz konusu olduğunda üretken emekçidirler. $\mathrm{O}$, kendi sermayesini onların emek-gücüyle değişir ve bu süreç aracılığıyla kendisini zenginleştirir. Tiyatrolar, eğlence yerleri, vb. için de durum aynıdır. Bu durumlarda, aktör, kamu karşısında bir sanatçı olarak davranır, ama kendi işvereni karşısında o bir üretken emekçidir (Marks \& Engels, 2009, s. 133134). 


\section{Sonuç}

Ulaşılan sonuçlar bakımından, Marks'ın estetik perspektifinden sanat, ideoloji ile bilim arasındadır. Sanat eseri için de aynı durum geçerlidir. Sanat eserinin anlatımı doğru, açık olmalı ve tarihsel toplumun özgün yönlerini ve düşüncelerini içine almalıdır. Sınıfsal ortamın psikolojisiyle şahısların psikolojisinin birer anlatımı olmalıdır. Dolayısıyla sanat eseri, gerçekliği ele alması bakımından bilimsel, sınıfsal ortamın yaratmış olduğu düşünce ve eylemleri anlatması bakımından ideolojiktir. Bundan dolayı Marks, sanat sanat içindir teorisini eleştirir. Gerçek bir sanatçı toplumu ilerlemesini ve değişmesini sağlayan bir entelektüeldir. Sanatın bir diğer özelliği olan entelektüel karakteri ortaya çıkar. Bir sanat eseri maddi dünyanın ilerici görüşlerini ve devrimci fikirlerini yansıtabilmesi için gerçekçi olmalıdır. Yani topluma ve o toplumun bağlantılı olduğu tarihsel vizyona bağlı olmalıdır. Sanatsal yöntemler yaratılarak soyut kavramlara ya da eksik tümelliklere bağlanmak sanatın görevi değildir. Sanat yalnızca basit bir şekilde doğayı kopyalayan, yetkinlikten yoksun, gerçeklerin çarpıtılmış dünyasının benzeri değildir. Sanatın bu dünyadaki misyonu devrimseldir. Sosyal ve tarihsel bir varlık olan insana kapitalizmin dünyasıyla ilgili epistomolojik bilgi aktarımı yaparken, insanların maddi dünyaya dair kavrayışlarını güçlendirir. Düşünceler ve kavramlar insanların maddi etkinliklerine bağımlı olduğu için sanat, toplumsal değişmenin ve dönüşmenin en etkin kuvvetidir. Maddi yaşamın karşıtlıklarından dünyaya dair bir izlenim oluşturur.

\section{Kaynakça}

Albert, M. (2007). Kapitalizm ötesinde yaşam: umudu gerçeğe dönüştürmek (T. Doğan, Çev.). İstanbul: Bgst Yayınları.

Benhabib, S. (2005). Eleştiri, norm ve ütopya (İ. Tekerek, Çev.). İstanbul: İletişim Yayınları.

Derrida, J. (2007). Marx’ın hayaletleri: borç durumu, yas çalışması ve yeni enternasyonal A. Tümertekin, Çev.). İstanbul: Ayrıntı Yayınları.

Eagleton, T. (2010). Estetiğin ideolojisi. B. Gözkan (Ed.). Ankara: Doruk Yayımc1lık.

Eagleton, T. (2011). Marx neden hakllydı? (O. Köymen, Çev.). İstanbul: Yordam Kitap.

Horkheimer, M. (2008). Akıl tutulması (O. Koçak, Çev.). İstanbul: Metis Yayıncılık.

Hünler, H. (2011). Estetik'in kisa tarihi: modern kültür ve sanat üzerine felsefi bir araştırma. Ankara: Doğu Batı Yayınları.

Mannheim, K. (2004). İdeoloji ve ütopya (M. Okyayuz, Çev.). Ankara: Epos Yayınları.

Marks, K. (1966). Felsefenin sefaleti (E. Başar, Çev.). İstanbul: Sol Yayınları.

Marks, K. (2003). Kapital: kapitalist üretimin eleştirel bir tarihi (A. Bilgi, Çev.). İstanbul: Eriş Yayınları.

Marks, K. (2016). Hegel'in hukuk felsefesinin eleştirisi (K. Somer, Çev.). İstanbul: Sol Yayınları.

Marks, K., \& Engels, F. (1995). Seçme yazışmalar 1: (1844-1869) (Y. Fincanc1, Çev.). İstanbul: Sol Yayınları.

Marks, K., \& Engels, F. (2004). Alman ideolojisi [Feuerbach] (S. Belli, Çev.). İstanbul: Sol Yayınları.

Marks, K., \& Engels, F. (2009). Yazın ve sanat üzerine (M. İ. Erdost, Yay. Haz.). İstanbul: Sol Yayınları.

Marks, K., \& Engels, F. (2018). Komünist manifesto (T. Bora, Çev.). İstanbul: İletişim Yayınları.

Moran, B. (2008). Edebiyat kuramları ve eleştiri. İstanbul: İletişim Yayınları. 
Nietzsche, F. (2002). Müziğin ruhundan tragedyanın doğuşu (İ. Z. Eyüboğlu, Çev.). İstanbul: Say Yayınları.

Rockmore, T. (2014). Marksizmden sonra Marx:Karl Marx’ın felsefesi (H. Türker, Çev.). İstanbul: Ayrıntı Yayınları.

Türdeş, M. (2004). Felsefe üzerine: Karl Marks-Friedrich Engels. İstanbul: Morpa Kültür Yayınları. 